\title{
UNION EFFECTS ON HEALTH INSURANCE PROVISION AND COVERAGE IN THE UNITED STATES
}

\author{
Thomas C. Buchmueller \\ John DiNardo \\ Robert G. Valletta
}

Working Paper 8238

http://www.nber.org/papers/w8238

\author{
NATIONAL BUREAU OF ECONOMIC RESEARCH \\ 1050 Massachusetts Avenue \\ Cambridge, MA 02138 \\ April 2001
}

We thank Leslie McGranahan and session attendees at the International Health Economics Association 2 nd World Conference for their comments. We also thank Emily Grimm and Carol D'Souza for helpful research assistance. The data and computer programs used for this study are available on request to the authors. The opinions expressed in this paper do not necessarily represent the views of the Federal Reserve Bank of San Francisco or the Federal Reserve System. The views expressed herein are those of the authors and not necessarily those of the National Bureau of Economic Research.

(C) 2001 by Thomas C. Buchmueller, John DiNardo and Robert G. Valletta. All rights reserved. Short sections of text, not to exceed two paragraphs, may be quoted without explicit permission provided that full credit, including $\odot$ notice, is given to the source. 
Union Effects on Health Insurance Provision and Coverage in the United States

Thomas C. Buchmueller, John DiNardo and Robert G. Valletta

NBER Working Paper No. 8238

April 2001

JEL No. I1, J3, J5

\begin{abstract}
During the past two decades, union density has declined in the United States and employer provision of health benefits has undergone substantial changes in extent and form. Using individual data spanning the years 1983-1997, combined with establishment data for 1993, we update and extend previous analyses of private-sector union effects on employer-provided health benefits. We find that the union effect on health insurance coverage rates has fallen somewhat but remains large, due to an increase over time in the union effect on employee "take-up" of offered insurance, and that declining unionization explains 20-35 percent of the decline in employee health coverage. The increasing union take-up effect is linked to union effects on employees' direct costs for health insurance and the availability of retiree coverage.
\end{abstract}

Thomas C. Buchmueller

Graduate School of Management University of California, Irvine Irvine, CA 92697

tcbuchmu@uci.edu

Robert G. Valletta

Federal Reserve Bank of San Francisco

101 Market Street

San Francisco, CA 94105

rob.valletta@oecd.org
John DiNardo

(on leave until August 2001 at)

UC Berkeley

Department of Economics

631C Evans Hall \#3880

Berkeley, CA 94720

jdinardo@uci.edu 


\section{Union Effects on Health Insurance Provision and Coverage in the United States}

\section{Introduction}

Because health insurance coverage in the United States largely is employment-based, there is substantial interest among labor and health economists in the factors that determine the extent, quality, and types of health coverage provided in the workplace. Past research has highlighted the important role of labor unions in determining benefit outcomes. In particular, through the preference revelation and enforcement mechanism inherent in the collective bargaining process, unions raise the level of benefits received by employees and the share of benefits in total compensation (Freeman 1981, Freeman and Medoff 1984). Recent data from the U.S. Department of Labor (1998) suggests that these effects potentially are large: as a share of total compensation, employer expenditures on health insurance in unionized work places are nearly double the level in non-union workplaces. Understanding the factors that generate these differences will provide insight into the changing nature and extent of health insurance coverage in the U.S. labor market and the role of unions in the contemporary U.S. economy.

The focus on unions is timely for several reasons. First, most existing analyses of union/non-union differences in fringe benefits used data from the 1970s and early 1980s. Since then, union density and influence have declined along with health insurance coverage for lesserskilled workers (Farber and Levy 2000, Currie and Yelowitz 2000); the union impact on benefits may have changed as well. Second, in response to rapidly rising health care costs, many employers have required employees to pay a larger share of premiums and have replaced traditional indemnity insurance with less costly but more restrictive managed care plans. Whereas previous studies of union effects focused on health coverage per se, union efforts now 
may be increasingly oriented towards influencing plan quality and resisting higher employee contributions.

To examine the role of unions in the provision of employer-based health insurance in the United States, we use individual survey data from several supplements to the Current Population Survey (CPS) and establishment data from a survey conducted in 1993 by the Robert Wood Johnson Foundation (RWJF). The individual data enable us to decompose employment-based insurance coverage and changes therein into portions attributable to insurance offers by employers, individual employee eligibility, and employee acceptance of offered insurance (takeup). We find that union workers are more likely than non-union workers to receive health benefits, and the difference mainly is explained by higher probabilities of insurance offers and higher take-up rates for union workers.

Although the union effect on offers is most pronounced for workers in small establishments, union effects on take-up are relatively uniform across small and large establishments. The take-up differential, which has increased over time, suggests that the health benefits available to union workers are of a higher quality, or perhaps lower cost, than those available to non-union workers. We examine an important aspect of health benefits that may explain the difference in take-up: direct employee costs, as reflected in premium contributions and plan cost-sharing (deductibles and co-payments). Results from the RWJF data indicate that workers in unionized establishments face lower direct costs than workers in non-union establishments.

The CPS and RWJF data sets also provide information on the prevalence and financing of retiree health coverage. Less research has been conducted on this benefit than on standard employee health benefits. However, the growing size of retirement cohorts, rising incidence of 
job loss among older, senior workers (Neumark, Polsky, and Hansen 1999, Valletta 1999), and declining incidence of retiree coverage (Loprest 1998; U.S. GAO 1997b, 1998) makes retiree health insurance an increasingly important policy issue. Consistent with unions' emphasis on the preferences of older workers, we find that the union effect on the provision of retiree health benefits is large and has grown over time.

In the next section, we discuss union effects on fringe benefit outcomes and changes in the market for health insurance provision. Section III describes our CPS and RWJ data and presents basic tabulations. In Section IV, we present results from regression analyses of health insurance outcomes; these regressions control for worker and establishment characteristics that are likely to differ between union and non-union workplaces. Section V summarizes the results and discusses their implications.

\section{Background and Previous Literature}

Early economic studies of fringe benefits (Rice 1964; Lester 1967) noted the likely importance of unions in increasing benefits, but due to data limitations did not investigate union effects in detail. The most comprehensive analysis of such effects is by Freeman and Medoff (1984). They argue that in non-union workplaces, where entry and exit are the primary adjustment mechanisms, employment and compensation outcomes are determined primarily by the preferences of "marginal" workers, who tend to be young, mobile, and have a relatively low demand for health benefits. By contrast, in a unionized environment the preferences of older, less mobile inframarginal workers are explicitly taken into account, through union voting and political processes that give voice to a wider set of workers than those at the margin. ${ }^{1}$

${ }^{1}$ The simplest statement of this view posits union bargaining based on the preferences of the median union member. As discussed by Farber (1986), however, the conditions necessary for union 
Unions may increase expenditures on health benefits and alter their form through other channels as well. Good health benefits are a highly visible and readily understood benefit, and as such may be especially attractive to union leaders, who need the approval of members in order to stay in power. They also may serve an additional political purpose with respect to bargaining with employers. Moreover, if the union helps to administer an insurance program across multiple work sites, the resulting economies of scale in plan provision may provide the basis for expansion of coverage and improvements in plan quality.

Existing empirical results support this view of union effects on employer-provided health insurance. Using data from the 1970s, Freeman and Medoff (1984) found that unionization substantially raised the probability workers were covered by employer-provided health plans. Woodbury and Bettinger (1991) found declining union membership to be the most important measured factor explaining the decline in employer-provided health insurance between 1979 and 1988. They and Even and MacPherson (1991) also found that the impact of unionization on insurance coverage fell during the 1980s. Since neither study distinguished between employer offers and employee take-up of coverage, the exact reasons for this decline are unclear.

Freeman and Medoff also analyzed data on employer expenditures for life health, and accident insurance combined, and found that the unionization effect on expenditures is larger than the effect on incidence, which suggests that improvements in plan quality are an important feature of union effects. Based on unadjusted comparisons from the 1981 National Medical Care Expenditure Survey, Freeman and Medoff found that health plans in union establishments provide more flexibility in regard to second opinions, and that the proportion of premiums paid by employers was 14 percent higher in union settings. Similarly, using establishment data from 
the year 1971, Goldstein and Pauly (1976) found that unionization significantly raises the probability that employees offer noncontributory health plans.

An updating of union effects on health insurance is especially important given the changes in health insurance markets that occurred during the 1980s and 1990s. Employers have responded to the rising cost of health care in ways that affect both the number of workers with insurance and the nature of the coverage held by insured workers. One response has been to increase the amount that employees are required to contribute directly for insurance (GAO 1997a; Gabel 1999). Several studies report that higher employee contributions reduce the percentage of workers who accept offered health insurance (Chernew et al. 1997; ShoreSheppard et al. 2000). Other studies indicate that a decline in take-up among workers who are offered health benefits is the primary reason for recent declines in private insurance coverage (Cooper and Schone 1997; Rice et al. 1997; Farber and Levy 2000).

Another development that is pertinent to understanding the role of unions in financing health care is a dramatic decline in retiree health benefits over the past 10 to 15 years. Loprest (1998) reports tabulations from BLS surveys indicating that the percentage of workers in medium and large firms that could continue their health insurance into retirement declined from 75 percent in 1985 to 46 percent a decade later. Other survey data also show a large decline in retiree health benefits (GAO 1997b, 1998). Given the important role of older workers in the formation of union bargaining goals, unions are likely to focus on the maintenance of retiree health benefits. 


\section{Data}

To examine the role of unions in the provision of employer-based health insurance in the United States, we use individual and establishment survey data. Our individual data come from several special supplements to the Current Population Survey (CPS): the Benefits Supplements conducted in May 1983, May 1988, and April 1993, a supplement regarding retiree health benefits conducted in August 1988, and the Contingent Work Supplements conducted in February 1995 and February 1997. In the 1983 Benefits Supplement survey, respondents were asked about receipt of employer-provided insurance. Beginning with the 1988 Benefits Supplement, respondents also were asked about employer insurance offers and individual eligibility. ${ }^{2}$ The 1993 Benefits Supplement included the widest range of health insurance questions, including ones about retiree health benefits and a limited set of health plan characteristics. This additional information is not available in the other Benefits Supplements or in the Contingent Work Supplements. One additional drawback of the Contingent Work Supplement data is the absence of information on establishment or firm size, which is an important determinant of both union status and health coverage. For all analyses discussed below, we restricted our CPS samples to employed individuals aged 20-64 at the time of the survey, and we excluded self-employed individuals and government workers. ${ }^{3}$

2 Currie and Yelowitz (2000) note that the ordering and wording of the health insurance questions differs between the Benefits Supplements and the Contingent Work Supplements. Although this may affect comparisons over time, Currie and Yelowitz also note that the trends evident in these data sets are similar to those evident for the same time period in the Survey of Income and Program Participation, in which the insurance questions did not change.

${ }^{3}$ The Contingent Work Supplement samples used in our analyses are smaller than the full sample from the monthly CPS because the questions regarding union status and earnings are posed only to respondents who will be rotating out of the sample at the end of that month (one quarter of the sample). In the Benefits Supplement data, the BLS matched information on earnings and union status from the May CPS survey, so we are not constrained to use only the outgoing rotation group observations; however, the Benefits Supplements were administered to only one-half of the monthly CPS sample. 
Table 1 lists tabulations that indicate the distribution of unionization and employerprovided health insurance in each CPS sample, with a breakdown by establishment size listed for 1993. The figures show that coverage by employer-provided health insurance plans declined by about 8 percentage points between 1983 and 1997; most of the decline occurred between 1988 and 1993, and it leveled off after 1993. ${ }^{4}$ Union membership density declined by about 9 percentage points between 1983 and 1997. The tabulations by establishment size using the 1993 data document the well-known positive relationship between establishment size and union membership, which we account for in the analyses. ${ }^{5}$

We also use establishment data from a telephone survey conducted in 1993 by the Robert Wood Johnson Foundation (RWJF). These data provide a means for validating and reinforcing results from the CPS data, and they also provide substantial independent detail on health plan characteristics. The RWJF sample was drawn from ten states: Colorado, Florida, Minnesota, New Mexico, New York, North Dakota, Oklahoma, Oregon, Vermont and Washington. Although the sample is designed to be representative of employers in these states rather than the entire U.S., aggregate economic and health insurance statistics for this group are fairly comparable to those for the nation as a whole (Cantor et al. 1995).

The full RWJF sample consists of 22,347 private establishments. We exclude from our analysis 493 observations ( 2.2 percent of the full sample) for which information on the union status of the firm's employees is missing. The RWJF survey also provides detailed information on all the health plans offered by each employer, and some of our analysis is done at the plan

${ }^{4}$ Our figures are very close to those presented by Farber and Levy (2000, Table 2).

${ }^{5}$ Establishment size also is available in the 1983 and 1988 supplements, but the tabulations by establishment size are very similar to those using the 1993 data. Prior studies (Bramley, Wunnava and Robinson 1989; Wunnava and Ewing 1999) have found that the effect of unions on benefits is strongest for employees of smaller firms. 
level. Our health plan sample contains observations on a total of 20,218 plans offered by 14,737 private establishments for which union status could be determined. ${ }^{6}$

Table 2 presents sample sizes and summary statistics on union status for the establishment portion of the RWJF data. Survey respondents were asked what percent of the firm's employees were union members. In much of our analysis we compare establishments with any union employees (hereafter union establishments) with those employing no union workers (non-union establishments). As shown in the first row of the table, establishments with nonzero union membership constitute 6.5 percent of the unweighted sample (column 2) and 20.9 percent of the employee-weighted sample (column 5$).^{7}$ In some analyses we divide the union establishments into two groups based on the percentage of employees who are union members, using 50 percent as the cut-off point. The figures in the table show that union establishments are split fairly evenly between these two categories. Similar to the individual data, the figures show that union membership is quite uncommon among employees of small establishments-fewer than 3 percent of firms with less than 10 workers employ any union members (columns 2 and 5) — and increases steadily with establishment size. Roughly one third of the establishments in the largest size category ( 250 or more employees) have some union employees.

Ideally, in estimating the effect of unions on plan characteristics, we would like to distinguish between effects operating within as well as across establishments. Unfortunately, this is not possible since there is ambiguity in the data as to which types of workers are eligible

\footnotetext{
${ }^{6}$ We lose 1003 health plan observations (4.7 percent of the total sample) due to missing data on union status.

${ }^{7}$ The unionization rates in Table 2 are not directly comparable to the rates calculated using the CPS data. The employee-weighted mean for the "percent union" variable is, however. For the full sample it equals 10.2 percent, which is slightly less than the rate of 12.5 percent in the April 1993 CPS Benefit Supplement.
} 
for which plans. ${ }^{8}$ Therefore, our plan-level analysis represents a comparison of plans offered by union and non-union establishments, controlling for employee and firm characteristics that vary at the establishment level.

\section{Results}

\section{Health Insurance for Active Employees}

Table 3 lists union/non-union differences in health insurance offers and receipt, estimated using our CPS data. ${ }^{9}$ We provide the same decomposition as used by Farber and Levy (2000). For years besides 1983, we are able to identify whether an individual's employer offers health insurance to any of its employees ("employer offers"), whether that employee is eligible for coverage ("eligible"), and whether the employee chooses to accept coverage ("take-up"); eligibility is defined conditional on employer offers, and take-up is defined conditional on offers and eligibility. The coverage rate is the product of these three components:

$\operatorname{Pr}($ covered $)=\operatorname{Pr}($ employer offer $) \bullet \operatorname{Pr}($ eligible $\mid$ offered $) \bullet \operatorname{Pr}($ take-up $\mid$ offered, eligible $)$

In the table, we list the union and non-union means for each outcome (e.g., the percentage of individuals whose employer offers insurance), the unadjusted difference between the union and non-union means, and several adjusted estimates of the union/non-union difference (the "union effect"). The adjusted differences in the fourth column are the coefficients on a union membership dummy variable from linear probability models that also include various

${ }^{8}$ Two survey questions elicit information regarding within-establishment differences between union and non-union workers. However, information regarding plan eligibility for non-union workers often is missing, and the survey provides no information regarding differences in the health benefits offered to union and non-union employees.

${ }_{9}$ The results for 1995 are similar to those for 1997 and therefore are omitted. 
individual characteristics and industry dummies, as listed at the bottom of the table. ${ }^{10}$ The adjusted differential from these regressions combines the effect of unionization on total compensation with its effect on the share of compensation received in the form of health insurance. Since data on each worker's total compensation are not available it is not possible to separate these two effects. Regressions reported in the final column include 5 establishment size dummies as explanatory variables (establishment size is unavailable in the 1997 data).

The unadjusted union/non-union differences in health insurance receipt range from about 22 percentage points in 1988 and 1997 to 27 percentage points in 1983. In years for which we are able to perform our decomposition, differences in the probability that employers offer insurance make a consistently large contribution to the union/non-union difference in coverage. When we control for individual characteristics and industry in the fourth column, the union effects on all components of the decomposition are reduced somewhat; controlling for establishment size (column 5) further reduces the union/non-union gap. Although we are unable to control for establishment size in the 1997 data, the pattern over time in the union effect on outcomes is similar in columns 4 and 5. The union effect on offers and coverage rose between 1988 and 1993 and then remained approximately constant or fell a bit.

The most striking result in Table 3 is the sharply rising union effect on take-up between 1988 and 1997. By 1997, the union effect on take-up was as large as the union effect on employer offers. Moreover, the unadjusted union and non-union figures in the first two columns of Table 3 indicate that the rising union take-up effect is primarily attributable to declining takeup among non-union workers: take-up declined for both groups, but it declined substantially more for non-union workers. This is consistent with the view that unions were relatively

${ }^{10}$ For all regressions with dichotomous dependent variables reported in this paper, we verified that estimation of probits produces results that are similar to those from the linear probability model; we 
successful in staving off an erosion of health-plan quality or cost sharing that reduced the attractiveness of employer-provided health plans between 1988 and 1997. Later in the paper we use data from the RWJF establishment survey to investigate some of the differences in health plan quality that may explain the large take-up effect.

Recall from Table 1 that between 1983 and 1997, health insurance coverage and union membership among private sector workers fell by 6.7 and 9.4 percentage points, respectively. The estimates from Table 3 can be extended to assess what fraction of the decline in insurance coverage is explained by the decline in unionization. We calculated a counterfactual coverage rate for 1997, with union density held at its 1983 level. We did so by using the 1997 regression coefficients and variable means from the specification of column 4 in Table 3, replacing the 1997 sample mean for the union variable with the corresponding value in the 1983 data. Compared to an actual coverage rate of 64.5 percent in 1997, the estimated counterfactual rate of 66.1 percent implies that the decline in union density explains 1.6 percentage points, or about 25 percent, of the 6.7 percentage point decline in insurance coverage between 1983 and 1997. If in addition to union density we hold the union effect (coefficient) to its 1983 value, we find that declining unionization and the changing union effect on coverage together explain about 36 percent of the decline in insurance coverage. The union impact is larger in this second decomposition because the union coefficient fell between 1983 and 1997. If we examine the change in coverage between 1983 and 1993, we can use the specification that also includes firm size dummies. When we do so, we find that declining unionization explains about 19 percent of the 5.7 percentage point drop in health coverage, and declining unionization combined with the changing union effect explains about 26 percent of the drop in health coverage.

use the latter for ease of interpretation. 
Table 4 presents additional regressions for the 1988 and 1993 CPS samples in which the union effect is allowed to vary by establishment size. ${ }^{11}$ These results show that pooling workers from all establishment sizes obscures large union effects for employees of smaller firms and large changes over time in several of the outcomes. In 1988, the union effect on insurance offers is restricted to establishments with fewer than 25 employees, and in both years the union effect on offers declines substantially as establishment size increases. Among workers in the smallest size category, the effect on offers increased considerably between the two years, from 19.4 percentage points in 1988 to 28.9 percentage points in 1993. As a result of this change and smaller percentage point increases in eligibility and take-up, the union/non-union difference in insurance coverage among workers in the smallest establishment size category increased by nearly two-thirds between 1988 and 1993.

In contrast to the results for offers, differences between union and non-union workers in take-up are more uniform across establishment size categories. In the 1988 sample, the union effect on take-up is slightly above 5.0 percentage points for the first four size categories (up to 99 employees), and it is a smaller but significant 2.9 percentage points for workers in establishments with 100 to 249 employees. With only one exception (50 to 99 employees), the union effect on take-up increased substantially within size categories between 1988 and 1993, becoming significant in the largest category as well. The relative uniformity of the union take-up effect across size categories, in terms of its level in 1993 and the increase between 1988 and 1993, is striking and suggests that unions in establishments of all sizes successfully bargained to improve or maintain the attractiveness of employer-provided health plans.

\footnotetext{
${ }^{11}$ Results for each year are based on a single regression in which we fully interact the union and establishment size dummies.
} 
Analysis of the RWJF establishment data provides further information regarding the effect of unions on employer provision of insurance. Table 5 compares offer rates for union and non-union establishments for the full RWJF sample and the sample broken down by establishment size, using the same size categories used for the CPS samples in Table 4. The results from the two data sets are quite similar. As in the individual data, the establishment-level results indicate that the union effect on health insurance offers is most pronounced for small establishments and essentially zero for large ones. Among establishments with fewer than 10 workers, those with union employees are 27.2 percentage points more likely to offer insurance than non-union establishments with similar observed characteristics. This matches fairly closely with the 28.9 percentage point effect on offers in the 1993 CPS data. Although this effect is large, it is important to keep in mind that fewer than 3 percent of establishments in this size grouping employ any union workers. The regression-adjusted union/non-union difference falls, both in magnitude and as a proportion of the unadjusted difference, in each of the next two size categories, though it remains statistically significant at conventional levels. The adjusted union effect is small and statistically insignificant for establishments with 50 or more employees. ${ }^{12}$

\section{Direct Employee Costs}

As noted in previous sections, the union effect on take-up operates within small and large establishments alike and has increased over time, suggesting that the health benefits available to union workers increasingly are of higher quality or lower cost than those offered to non-union workers. Using the RWJF establishment data, we now examine an important aspect of health benefits that may help explain the union take-up effect: direct employee costs, as reflected in

\footnotetext{
${ }^{12}$ In unreported regressions (available on request) we examined whether the union effect varies with the percent organized and found a small positive but insignificant difference.
} 
premium contributions and plan cost-sharing (deductibles and co-payments). We begin by investigating union effects on the percentage share of single and family premiums paid by employers. We use this share variable rather than a dollar-denominated measure because variation in the latter is likely to reflect cost considerations that are unrelated to the influence of unions, whereas the share variable is more likely to reflect the direct impact of union bargaining power.

Our analysis is complicated by the distribution of the employer contribution variable. The employer's percentage share, $S$, is distributed as a continuous variable on the percentage point interval $[0,100]$, but a large fraction of the observations take on the maximum value of 100 (and a small fraction take on the minimum value of 0 ). The large density mass at the maximum makes it difficult to choose an appropriate functional form for regression analysis and raises concern that the results will be sensitive to specification. ${ }^{13}$ We therefore apply a semi-parametric estimation approach that controls for establishment characteristics without imposing parametric restrictions on the distribution of the dependent variable or the union effect.

This approach is an application of the technique developed by DiNardo, Fortin, and Lemieux (1996) and applied by DiNardo and Lemieux (1997) to a problem similar to ours (see the latter for a more formal presentation). Consider first a simple comparison of the observed distribution of $S$ in the union and non-union sectors. If union and non-union establishments are identical in terms of characteristics other than unionization that affect $S$, this comparison provides an unbiased estimate of the union effect. In practice, however, this simple estimate will be biased because the distribution of related characteristics differs across sectors. Stated

13 This setting may seem like a natural application for a Tobit model. However, unlike the classic Tobit case, in which excess density mass arises from censoring, in our case $S=100$ is a meaningful 
alternatively, the unadjusted non-union distribution puts too much weight on establishments with characteristics that are unusual among unionized establishments and not enough weight on establishments with characteristics that are common among unionized establishments. To impose the same distribution of characteristics in the two samples - i.e., to control for related characteristics - we can reweight the non-union observations by:

$$
W=\mathrm{p}(U=1 \mid X) /(1-\mathrm{p}(U=1 \mid X))
$$

where $\mathrm{p}(U=1 \mid X)$ is the probability that an establishment is unionized, conditional on a vector of related characteristics $X$. This procedure assigns weights $W$ that increase in direct proportion to the relative likelihood that an observation with characteristics $X$ is unionized, thereby placing more weight on non-union establishments that are more similar to union establishments in terms of the characteristics $X$. Whereas differences between the unadjusted union and non-union distributions are due to unionization and differences in related establishment characteristics, differences between the unadjusted union distribution and the adjusted non-union distribution are due to unionization only. The conditional probabilities $\mathrm{p}(U=1 \mid X)$ are not observed but can be estimated by means of a logit model over the entire sample. In this regression, the dependent variable is an indicator for whether the establishment is unionized, and the regressors $(X)$ are the same control variables that were used for analysis of union effects on employer offers (Table 5).

The results of this analysis are reported in Table 6. The top panel presents results for union effects on employers' share of single coverage premiums. The table lists results for the unadjusted union and non-union distributions of $S$ and the non-union distribution adjusted for differences in establishment characteristics. The results reported include the mean and median of and inefficient in the presence of heteroscedasticity (Johnston and DiNardo 1997). 
$S$ along with the percentage of employers that pay full cost $(S=100)$. Consistent with previous studies using data from the 1970s (Goldstein and Pauly 1976; Freeman and Medoff 1984), the results indicate strong effects of unionization on the generosity of employer premium contributions. On an unadjusted basis (column 4), single coverage plans offered by union establishments are 11.5 percentage points more likely to be fully financed by employers (49.4 percent vs. 37.9 percent), and the mean and median employer share both are noticeably larger in unionized establishments.

Controlling for establishment characteristics increases the size of the union/non-union differential in employer contributions for single coverage. Conditional on establishment characteristics, single coverage plans offered by union establishments are about 20 percentage points more likely to be fully financed by employers (49.4 percent vs. 29.9 percent). ${ }^{14}$ The difference in the median value of $S$ between plans offered by union and non-union establishments is 13 points ( 98 vs. 85). Because of the way $S$ is truncated, the mean difference is somewhat smaller (9.1 percentage points). To put these differences in perspective, the median and mean premiums for single coverage in the RWJF data set are \$148 and \$157 per month, respectively. Thus, the 13 percentage point difference in the median values of $S$ implies that union workers pay roughly $\$ 20$ less per month for single coverage than non-union employees; the difference of 9.1 percentage points in the means of $S$ implies a difference of about $\$ 13$.

The distributions of employer contributions for family coverage (lower panel of Table 6) are different from those for single coverage. Most notably, employers are less likely to pay the entire family coverage premium. However, the contrast between union and non-union establishments is similar to that for single coverage contributions. Conditional on establishment 
characteristics, union establishments are 15 percentage points more likely than non-union establishments to pay the full premium for family coverage ( 27.6 percent versus 12.3 percent). The average union effect is 6 to 10 percentage points when the distributions are compared at either the mean or the median. Applied to the median family premium in the RWJF data set (\$381), this translates to a difference of roughly $\$ 23$ to $\$ 38$ in the amount that union and nonunion workers are required to contribute each month for family coverage. ${ }^{15}$

Another important aspect of direct employee costs is cost-sharing provisions such as deductibles and co-payments, for which we have information from the RWJF survey. Since the relevant cost-sharing variables differ by plan type, we examine them separately. ${ }^{16}$ The plan types include: indemnity plans, which allow patients to seek care from essentially any provider; preferred provider organizations (PPOs), which provide financial incentives to seek care from a panel of providers who have agreed to accept the insurer's (discounted) fee schedule and oversight; and Health Maintenance Organizations (HMOs), which typically require less costsharing by patients than the other plans but place greater restrictions on which providers can be used. Forty-four percent of the plans in the data set are indemnity plans, 32 percent are PPOs, and 24 percent are HMOs. We examined unadjusted and regression-adjusted union/non-union

\footnotetext{
${ }^{14} \mathrm{We}$ used a bootstrap technique to estimate the sampling distribution of the union/non-union differences reported in Table 6 . All of the differences are statistically significant at the 1-percent level, except for the difference in the median family contribution, which is significant at the 5-percent level.

${ }^{15}$ An alternative estimate of union effects could be obtained by reversing our approach and applying the non-union distribution of characteristics to the union sample. In general, this produces approximately the same results as those reported in Table 6, except we obtain a larger estimate of the union effect on the median employer contribution for family coverage using this alternative approach.

${ }^{16}$ These estimates could be affected by unobserved determinants of plan type that differ between union and non-union establishments. A simple analysis based on observable characteristics, however, is reassuring in this regard. When we control for observables, there is no significant difference between union and non-union establishments in the probability of employees being offered at least one HMO, at least one PPO, or at least one non-HMO plan (PPO or indemnity). The only significant difference in plan offerings is that union establishments are 7 percentage points more likely to offer their employees at least one indemnity plan.
} 
differences. For the sake of brevity we summarize the results here but do not report them in tables. $^{17}$

With traditional indemnity insurance and PPO plans, meaningful variation in cost sharing is captured primarily by the plan deductible, which is a fixed claim amount that patients must pay. The mean deductible for indemnity plans offered by union establishments is $\$ 100$ lower than that offered by non-union establishments (\$200.05 vs. \$300.70). When we control for establishment characteristics the differential is cut roughly in half $(\$ 54)$, but remains statistically significant at the 1-percent level. PPO plans typically require lower deductibles for "innetwork" providers than for "out-of-network" providers. The mean in-network PPO deductible is lower for union than for non-union establishments, but the difference is small and statistically insignificant when we adjust for observables. However, mean deductibles for out-of-network PPO care are \$69 lower in union establishment plans, and the regression-adjusted difference is a statistically significant $\$ 55$. On net, the results for indemnity and PPO plans indicate a significantly lower employee cost burden in unionized establishments.

By contrast with indemnity and PPO plans, HMO plans impose no deductible, instead charging a fixed dollar copayment (usually between $\$ 5$ and $\$ 25$ ) per physician visit. The unadjusted and regression-adjusted union effects on this outcome are quite small and statistically insignificant, perhaps because in HMO plans it is the breadth and quality of the provider network, rather than cost-sharing parameters, that differentiates higher and lower quality plans.

${ }^{17}$ The sample sizes for our analysis of plan cost sharing are 8891 indemnity plans, 6543 PPOs, and 4783 HMOs. The control variables are the same as those used in the RWJF offer regressions. In estimating the standard errors we account for the fact that some establishments offer several plans and therefore contribute multiple observations to the estimation sample 


\section{Retirement Coverage}

In the final part of our analysis, we examine union/non-union differences in retiree health benefits. In the August 1988 and April 1993 CPS files, respondents were asked whether their current employer will provide health insurance at a group rate through their retirement years. ${ }^{18}$ Results for this outcome are reported in Table 7. Except for the dependent variable and sample restriction, the regression specifications are identical to those from Table 3, which presented results for current health insurance coverage. We restricted the sample in both years to workers who at the time of the survey were receiving coverage through an employer-provided plan. ${ }^{19}$ Therefore, the results reported in Table 7 indicate the effect of unions on retiree coverage only, not the combined effect of unions on active and retiree coverage (we discuss the latter below).

The results show that the union effect on employer provision of retiree benefits increased substantially between 1988 and 1993. The unadjusted union effect rose from 10.1 percentage points (Panel A, third column) to 16.7 percentage points (Panel B, first row, third column). Controlling for individual characteristics, the adjusted differential rose about 10 percentage points, from a statistically insignificant effect of 4.5 percentage points in 1988 to a significant effect of 14.6 percentage points in $1993 .^{20}$ The increase in the union effect on retiree benefits between these two years is consistent with the implied improvement in the quality of union plans associated with the rising union effect on take-up (Table 3).

${ }^{18}$ The questions on retiree insurance were asked of workers 40 and older in the August 1988 survey and 46 and older in April 1993. For the sake of comparability, we use the latter cut off for both years.

${ }^{19}$ In the 1988 survey, the questions regarding retiree coverage were asked only of workers who were covered by an employer-provided plan, while in the 1993 survey they were asked of workers whose employers offered a plan. The results for the 1993 sample are virtually identical to those listed in Table 7 when we use employer offers rather than employee coverage to define the analysis sample.

${ }^{20}$ Compared to our results, MacPherson (1992) found a slightly larger and statistically significant effect of unionization on retiree coverage in the August 1988 supplement data. In auxiliary regressions (available on request), we verified that the difference in our results is explained by his inclusion of public sector employees and small differences in regression specification. 
There is no information on establishment size in the 1988 data, so we can not compare results over time for our most complete specification. However, in the 1993 data adding establishment size dummies reduces the estimated union effect on retiree coverage only slightly, from 14.6 to 12.8 percentage points. Although not reported in a table, additional regressions revealed no significant differences in the union effect across establishment size categories.

Relative to the average coverage rates for non-union employees, unions raise the incidence of current coverage and retirement coverage by essentially the same amount, about 21 percent. ${ }^{21}$ Moreover, if we assume that all workers not covered by a current plan also do not have retiree coverage available to them, we can incorporate the observations for individuals who were not asked about retirement coverage and obtain an estimate of the combined effect of unions on active and retiree coverage. When we do so for the results reported in column (5) in the first row of panel $\mathrm{B}$, the estimated union effect rises from 12.8 to 17.5 percentage points. This increases the union effect on retirement coverage, relative to the average retirement coverage rate for non-union employees, from 21.4 percent to 29.2 percent. $^{22}$

In 1993, respondents also were asked whether they expect their employer to pay the full cost of retiree coverage. Estimates of the union effect on this outcome are reported in Panel B of Table 7. The analysis sample for this variable is restricted to individuals whose employers offer retiree coverage. On an unadjusted basis union employees are about twice as likely as non-union

${ }^{21}$ For active coverage, this calculation is based on results from Table 3, panel C, fourth row: $0.132 / 0.624=0.212$. For retiree coverage, this calculation is based on results from Table 7, panel B, first row: $0.128 / 0.598=0.214$.

${ }^{22}$ In the 1988 and 1993 data, about 30 percent of respondents answer "don't know" when asked about the availability of retiree benefits from their current employer. Moreover, union workers are about 8 to 10 percentage points less likely than non-union workers to answer this way. To assess the implication of non-response for our estimated union effects, we start with the plausible assumption that individuals who respond "don't know" have a lower rate of retiree coverage than individuals who provide a definitive response. In the limit, no one in the non-response group has retiree coverage. If we impose this extreme assumption, the estimated union impact on retiree coverage is increased by about 5 
employees to be eligible for a retirement health plan for which their employer pays the full cost; the adjusted differences are nearly as large.

The RWJF establishment survey also asked about employer-provided retiree health benefits; regressions from that data set offer additional evidence on the topic and a check on the CPS results. Table 8 lists the effect of unions on the provision of retiree health benefits in the RWJF data. The layout is similar to Table 5, with one exception: because the sample size is reduced by restriction of the retiree coverage sample to establishments that offer health insurance to active employees, we report the sample sizes in the first column. The figures in the first row show that 56 percent of union establishments and 31 percent of non-union establishments that offer health insurance to active employees also offer retiree health benefits, implying an unadjusted union effect of 25 percentage points. Controlling for observable firm and worker characteristics reduces the union effect to 7.9 percentage points. This is much larger than the adjusted union effect on coverage for active employees in the RWJF data (2.9 percentage points; Table 5). ${ }^{23}$ Moreover, compared to union effects on coverage for active employees that were small and insignificant in establishments with 50 or more employees, the union effect on retiree benefits is fairly large and statistically significant for all but the very largest establishment size category. Overall, we find relatively large and consistent union effects on employer provision of retiree health benefits in our 1993 individual and establishment data. ${ }^{24}$

percentage points for the 1988 data and 3 percentage points for the 1993 data. This does not alter any substantive conclusions, including the large increase in the union effect between 1988 and 1993.

${ }^{23}$ The combined effect of unions on active and retiree coverage -obtained by assuming that all establishments that do not offer current coverage also do not offer retiree coverage-is only slightly larger ( 8.3 percentage points) than the effect on retiree coverage alone.

${ }^{24} \mathrm{We}$ also estimated models that account for differences among unionized establishments by replacing the single union dummy with two indicator variables denoting establishments in which fewer or greater than one-half of the employees are union members. Although we do not report these results in a table, we found that the union effect on retiree health coverage is significantly larger in majority-union establishments than it is in minority-union establishments. 


\section{Conclusions}

In this paper, we provided updated and expanded estimates of the impact of unions on the extent and form of employer-provided health coverage. This updating is important in light of declining union membership and significant changes in the U.S. health care delivery system over the past several decades. Using individual data from CPS supplements, we decomposed the effect of union membership on health insurance coverage into effects on intermediate outcomes that determine coverage: employer offers, individual employee eligibility, and employee take-up of offered insurance. Although the estimated union effect on the probability of coverage fell somewhat between 1983 and 1997, the union effect on the probability of employee take-up rose substantially. Moreover, although the union effect on offers is relatively small among the largest establishments, in which health benefits typically are provided even in the absence of unions, the union effect on take-up and its increase over time were relatively uniform across small and large establishments.

The pattern in the union take-up differential suggests that the health benefits available to union workers increasingly are of a higher quality, or perhaps lower cost, than are those available to non-union workers. This explanation is supported by our finding in the RWJF establishment data that employees at unionized firms pay lower direct costs for health coverage. Our findings regarding employer provision and financing of post-retirement health insurance also are consistent with our explanation of the rising union take-up effect. We found union effects on retiree coverage that are as large or larger than union effects on coverage for current employees. In the CPS data, the union effect on the probability that employers pay the full cost of retiree coverage is especially large. The union effect on retiree coverage grew substantially between 1988 and 1993, at the same time that the union effect on coverage for current employees was 
growing. Moreover, while union effects on active employee coverage are limited to small firms (since nearly all firms with more than 50 employees offer insurance), our CPS and RWJF results indicate that unions raise access to retiree health benefits in firms of all sizes.

These results are quantitatively important and have implications for the changing provision of health insurance for workers and retirees. Our estimates suggest that declining unionization explains 20 to 35 percent of the decline in employer-provided health insurance among private sector employees during the period 1983-97. This is as large or larger than the contribution of declining unionization to the rise in male earnings inequality during the $1980 \mathrm{~s}$ (Fortin and Lemieux 1997). The union effect on retiree coverage also is large, and although our data are limited in this regard, declining unionization is likely to explain a large share of the decline in retiree benefits. The decline in health insurance for the elderly suggests that public resources for elderly care may become increasingly strained as current and future generations of workers retire, unless expansion of collective bargaining or other means are used to encourage private provision of retiree health benefits. 


\section{References}

Bramley, Donald G., Phanindra V. Wunnava, and Michael D. Robinson. 1989. "A Note on Union-Non-Union Benefit Differentials and Size of Establishment." Economics Letters 30(1), pp. 85-88.

Cantor, Joel C., Stephen H. Long, M. Susan Marquis. 1995. "Private EmploymentBased Health Insurance in Ten States.” Health Affairs 14(2), pp. 199-211.

Chernew, Michael, Kevin Frick, and Catherine G. McLaughlin. 1997. "The demand for health insurance coverage by low-income workers: Can reduced premiums achieve full coverage?" Health Services Research 32(4), pp. 453-470.

Cooper, Phillip F, and Barbara S. Schone. 1997. "More Offers, Fewer Takers for Employment-Based Health Insurance: 1987 and 1996." Health Affairs 16(6), pp. 142-149.

Currie, Janet, and Aaron Yelowitz. 2000. "Health Insurance and Less Skilled Workers." In David Card and Rebecca Blank, eds., Finding Jobs: Work and Welfare Reform, New York: Russell Sage.

DiNardo, John, Nicole Fortin, and Thomas Lemieux. 1996. "Labor Market Institutions and the Distribution of Wages, 1973-1992: A Semiparametric Approach." Econometrica 64(5), pp. 1001-1044.

DiNardo, John, and Thomas Lemieux. 1997. "Diverging Male Wage Inequality in the United States and Canada, 1981-1988: Do Institutions Explain the Difference?" Industrial and Labor Relations Review 50(4), pp. 629-651.

Even, William E. and David A. McPherson. 1991. "The Impact of Unionism on Fringe Benefit Coverage." Economics Letters 36, pp. 87-91.

Farber, Henry S. 1986. "The Analysis of Union Behavior." In Handbook of Labor Economics, Volume 2, edited by Orley C. Ashenfelter and Ricard Layard. Amsterdam: North Holland, pp. 1039-1090.

Farber, Henry S., and Helen Levy. 2000. "Recent Trends in Employer-Sponsored Health Insurance Coverage: Are Bad Jobs Getting Worse?" Journal of Health Economics 19(1), pp. 93-119.

Fortin, Nicole M., and Thomas Lemieux. 1997. "Institutional Changes and Rising Wage Inequality: Is There a Linkage?" Journal of Economic Perspectives 11(2), pp. 75-96.

Freeman, Richard B. 1981. "The Effect of Unionism on Fringe Benefits." Industrial and Labor Relations Review 34(4), pp. 489-509. 
Freeman, Richard B., and James L. Medoff. What Do Unions Do? New York: Basic Books, 1984.

Gabel, Jon. 1999. "Job-Based Health Insurance, 1977-1998: The Accidental System Under Scrutiny." Health Affairs 18(6): 62-74.

Goldstein, Gerald S., and Mark V. Pauly. 1976. "Group Health Insurance as a Local Public Good." In R. Rosett, ed., The Role of Health Insurance in the Health Services Sector. Cambridge, MA: National Bureau of Economic Research.

Johnston, Jack, and John DiNardo. 1997. Econometric Methods. New York: McGraw Hill.

Lester, Richard. 1967. "Benefits as a Preferred Form of Compensation." Southern Economic Journal 33, pp. 488-495.

Loprest, Pamela. 1998. "Retiree Health Benefits: Availability from Employers and Participation by Employees." Gerontologist 38(6), pp. 684-694.

Macpherson, David A. 1992. "Employer-provided retiree health insurance: Who is covered?" Economics Letters 39(1), pp. 95-100.

Neumark, David, Daniel Polsky, and Daniel Hansen. 1999. "Has Job Stability Declined Yet? New Evidence for the 1990s." Journal of Labor Economics 17(4, part 2): S29-S64.

Rice, Robert. 1964. "Skill, Earnings, and the Growth of Wage Supplements." American Economic Review, pp. 583-593.

Rice, Thomas, et al. 1997. "Trends in Job-Based Health Insurance." Report Submitted to the Kaiser Family Foundation (October).

Shore-Sheppard, Lara, Thomas C. Buchmueller, and Gail A. Jensen. 2000. "Medicaid and Crowding Out of Private Insurance: A Re-examination Using Firm Level Data." Journal of Health Economics 19(1), pp. 61-91.

U.S. Department of Labor, Bureau of Labor Statistics. 1998. "Employer Costs for Employee Compensation, 1986-98. Bulletin 2508, December.

U.S. General Accounting Office. 1997a. "Employment-Based Health Insurance: Costs Increase and Family Coverage Decreases." GAO/HEHS-97-35.

U.S. General Accounting Office. 1997b. "Erosion in Employer-Based Health Benefits for Early Retirees." GAO/HEHS-97-150.

U.S. General Accounting Office. 1998. "Erosion in retiree Health Benefits Offered by Large Employers." GAO/HEHS-98-110. 
Valletta, Robert G. 1999. "Declining Job Security.” Journal of Labor Economics 17(4, part 2): S170-S197.

Woodbury, Stephen and Douglas Bettinger. 1991. "The Decline of Fringe Benefit Coverage in the 1980s" in Randall W. Eberts and Erica L. Groshen, eds., Structural Changes in US Labor Markets: Causes and Consequences. New York: ME Sharpe, pp. 105-138.

Wunnava, Phanindra V., and Bradley T. Ewing. 1999. "Union-Non-union Differentials and Establishment Size: Evidence from the NLSY." Journal of Labor Research 20(2), pp. 177-183. 
Table 1: Unionization and Employer-Provided Health Coverage, CPS Benefits Supplement Data

\begin{tabular}{|c|c|c|c|}
\hline & $\begin{array}{c}\text { (1) } \\
\text { sample size }\end{array}$ & $\begin{array}{c}\text { (2) } \\
\text { percent union } \\
\text { members }\end{array}$ & $\begin{array}{c}(3) \\
\text { percent covered by } \\
\text { employer health plan }\end{array}$ \\
\hline \multicolumn{4}{|c|}{ May 1983} \\
\hline full sample & 15,637 & .209 & .712 \\
\hline \multicolumn{4}{|c|}{ May 1988} \\
\hline full sample & 15,254 & .149 & .701 \\
\hline \multicolumn{4}{|c|}{ April 1993} \\
\hline full sample & 15,179 & .125 & .655 \\
\hline \multicolumn{4}{|l|}{ By establishment size: } \\
\hline$<10$ & 3,066 & .037 & .379 \\
\hline $10-24$ & 2,201 & .061 & .531 \\
\hline $25-49$ & 1,837 & .099 & .620 \\
\hline 50-99 & 1,806 & .144 & .707 \\
\hline $100-249$ & 2,171 & .156 & .766 \\
\hline $250+$ & 4,098 & .211 & .860 \\
\hline \multicolumn{4}{|c|}{ February 1995 (N=8,911) } \\
\hline full sample & 8,911 & .113 & .636 \\
\hline \multicolumn{4}{|c|}{ February $1997(\mathrm{~N}=8,144)$} \\
\hline full sample & 8,144 & .115 & .645 \\
\hline
\end{tabular}

Note: All tabulations were weighted using the supplement weights. The samples are restricted to private-sector employees aged 20-64 at the time of the survey. 
Table 2: Establishment Union Density, by Establishment Size, RWJF Data

\begin{tabular}{|c|c|c|c|c|c|c|c|}
\hline & \multirow[b]{2}{*}{$(1)$} & \multicolumn{3}{|c|}{$\begin{array}{l}\text { Unweighted tabulation of } \\
\text { establishments (percentage) }\end{array}$} & \multicolumn{3}{|c|}{$\begin{array}{l}\text { Employee-weighted tabulation } \\
\text { of establishments (percentage) }\end{array}$} \\
\hline & & (2) & (3) & (4) & (5) & (6) & (7) \\
\hline & & \multicolumn{3}{|c|}{$\%$ of Employees in a Union } & \multicolumn{3}{|c|}{$\%$ of Employees in a Union } \\
\hline & $\begin{array}{l}\text { Sample } \\
\text { Size }\end{array}$ & $>0$ & 0 to 50 & $>50$ & $>0$ & 0 to 50 & $>50$ \\
\hline All Firms & 21,854 & $6.53 \%$ & $2.83 \%$ & $3.61 \%$ & $20.85 \%$ & $10.33 \%$ & $10.30 \%$ \\
\hline By Establishment Size & & & & & & & \\
\hline$<10$ employees & 10,426 & 2.34 & 1.10 & 1.23 & 2.62 & 1.14 & 1.47 \\
\hline 10 to 24 employees & 5,532 & 4.66 & 2.19 & 2.40 & 5.73 & 2.99 & 2.70 \\
\hline 25 to 49 employees & 2,360 & 8.81 & 3.43 & 5.34 & 10.81 & 4.36 & 6.44 \\
\hline 50 to 99 employees & 1,483 & 14.11 & 6.00 & 7.82 & 19.07 & 6.83 & 12.10 \\
\hline 100 to 249 employees & 1,249 & 20.78 & 7.13 & 12.89 & 23.53 & 7.34 & 15.92 \\
\hline $250+$ employees & 779 & 31.50 & 15.53 & 15.79 & 38.25 & 23.23 & 14.97 \\
\hline
\end{tabular}

Note: There are 25 establishments for which it is possible to determine the presence of a union but not the percent of workers who are members. Because of this (and rounding), the second and third column of each panel (columns 3-4 and 6-7) may not sum to equal the first (columns 2 and $5)$. 
Table 3: Union/Non-union Differences in Health Insurance
Offers and Receipt, CPS Benefits Supplement Data

\begin{tabular}{|c|c|c|c|c|c|}
\hline & (1) & (2) & (3) & (4) & (5) \\
\hline \multicolumn{6}{|c|}{ Panel A: $1983(\mathrm{~N}=15,637)$} \\
\hline \multirow{4}{*}{ Covered } & \multirow{3}{*}{$\begin{array}{l}\text { Union } \\
.929\end{array}$} & \multirow{3}{*}{$\begin{array}{c}\text { Non-union } \\
.655\end{array}$} & \multicolumn{3}{|c|}{ Difference (union - non-union) } \\
\hline & & & Unadjusted & Adjusted & Adjusted (size) \\
\hline & & & .274 & .211 & .151 \\
\hline & & & & & \\
\hline \multicolumn{6}{|c|}{ Panel B: $1988(\mathrm{~N}=15,254)$} \\
\hline & & & \multicolumn{3}{|c|}{ Difference (union - non-union) } \\
\hline & Union & Non-union & Unadjusted & Adjusted & Adjusted (size) \\
\hline Employer & .938 & .816 & .122 & .095 & .039 \\
\hline Offers & & & $(.008)$ & $(.009)$ & $(.008)$ \\
\hline \multirow[t]{2}{*}{ Eligible } & .962 & .881 & .081 & .056 & .049 \\
\hline & & & $(.007)$ & $(.008)$ & $(.008)$ \\
\hline Take-up & 987 & .929 & $\begin{array}{l}.057 \\
(006)\end{array}$ & $\begin{array}{c}.033 \\
(006)\end{array}$ & .027 \\
\hline \multirow[t]{2}{*}{ Covered } & .890 & 668 & .222 & .152 & .097 \\
\hline & & & $(.010)$ & $(.010)$ & $(.010)$ \\
\hline
\end{tabular}

\begin{tabular}{lccccc}
\hline & \multicolumn{5}{c}{ Panel C: $1993(\mathrm{~N}=15,179)$} \\
\cline { 3 - 5 } & & & \multicolumn{3}{c}{ Difference (union - non-union) } \\
\cline { 4 - 6 } Employer & Union & Non-union & Unadjusted & Adjusted & Adjusted (size) \\
Offers & .946 & .792 & .154 & .141 & .078 \\
Eligible & & & $.010)$ & $(.009)$ & $(.009)$ \\
& .961 & .908 & .053 & .032 & .027 \\
Take-up & & & $(.007)$ & $(.007)$ & $(.007)$ \\
& .957 & .867 & .090 & .068 & .057 \\
Covered & & & $(.008)$ & $(.009)$ & $(.009)$ \\
& .870 & .624 & .246 & .194 & .132 \\
& & & $.012)$ & $(.011)$ & $(.011)$ \\
\end{tabular}

\begin{tabular}{lccccc} 
& \multicolumn{5}{c}{ Panel D: $1997(\mathrm{~N}=8,144)$} \\
\cline { 3 - 5 } & Union & Non-union & Unadjusted & Ddjusted & Adjusted (size) \\
Employer & .928 & .816 & .112 & .100 & N/A \\
Offers & & & $.013)$ & $(.013)$ & \\
Eligible & .946 & .909 & .037 & .021 & N/A \\
& & & $.010)$ & $(.010)$ & \\
Take-up & .951 & .835 & .116 & .100 & N/A \\
& & & $. .013)$ & $(.014)$ & N/A \\
Covered & .835 & .620 & .215 & .175 & \\
& & & $(.016)$ & $(.016)$ &
\end{tabular}

Note: All estimates were obtained using the survey supplement weights. Standard errors are in parentheses. The first set of adjusted estimates (column 4) are the union coefficients from linear probability models that include controls for education (4 category dummies), age, age squared, female, whether married, female by married, race/ethnicity (dummy variables for black and hispanic), a dummy variable for msa residency, 3 region dummies, and 8 major industry dummies. The estimates in the final column are based on a specification that also includes 5 establishment size dummies (10-24, 25-49, 50-99, and 100-249, 250+; <10 is the omitted category; 4 dummies in 1983).

$\mathrm{N} / \mathrm{A}=$ not available 
Table 4: Union Effects on Health Insurance Outcomes, by Establishment Size, 1988 and 1993 CPS Benefits Supplements

\begin{tabular}{|c|c|c|c|c|c|c|}
\hline & \multicolumn{6}{|c|}{ Union Effects by Establishment Size (number of employees) } \\
\hline & (1) & (2) & (3) & (4) & (5) & (6) \\
\hline & $<10$ & $10-24$ & $25-49$ & $50-99$ & $100-249$ & $250+$ \\
\hline \multicolumn{7}{|l|}{1988} \\
\hline \multirow[t]{2}{*}{ Offer } & .194 & .146 & .033 & .023 & .006 & .017 \\
\hline & $(.030)$ & $(.027)$ & $(.021)$ & $(.022)$ & $(.018)$ & (.012) \\
\hline \multirow[t]{2}{*}{ Eligible } & .007 & .107 & .057 & .069 & .046 & .038 \\
\hline & $(.032)$ & $(.027)$ & $(.021)$ & $(.021)$ & $(.017)$ & $(.011)$ \\
\hline \multirow[t]{2}{*}{ Take-up } & .052 & .054 & .052 & .054 & .029 & .006 \\
\hline & $(.026)$ & $(.021)$ & $(.017)$ & $(.016)$ & $(.013)$ & $(.008)$ \\
\hline \multirow[t]{2}{*}{ Covered } & .175 & .238 & .110 & .124 & .069 & .060 \\
\hline & $(.037)$ & $(.033)$ & $(.026)$ & $(.027)$ & $(.022)$ & $(.015)$ \\
\hline \multicolumn{7}{|l|}{1993} \\
\hline \multirow[t]{2}{*}{ Offer } & .289 & .199 & .067 & .078 & .044 & .040 \\
\hline & $(.033)$ & $(.030)$ & $(.026)$ & $(.023)$ & $(.020)$ & $(.013)$ \\
\hline \multirow[t]{2}{*}{ Eligible } & .050 & .041 & .060 & .029 & .018 & .019 \\
\hline & $(.030)$ & $(.026)$ & $(.023)$ & $(.019)$ & $(.016)$ & $(.011)$ \\
\hline \multirow[t]{2}{*}{ Take-up } & .072 & .124 & .126 & .058 & .051 & .032 \\
\hline & $(.035)$ & $(.030)$ & $(.026)$ & $(.022)$ & $(.019)$ & $(.012)$ \\
\hline \multirow[t]{2}{*}{ Covered } & .286 & .271 & .201 & .126 & .097 & .083 \\
\hline & $(.040)$ & $(.037)$ & $(.032)$ & $(.028)$ & $(.025)$ & $(.016)$ \\
\hline
\end{tabular}

Note: All estimates were obtained using the survey supplement weights. Standard errors are in parentheses. The estimated union effects are obtained from the union coefficients and size interaction coefficients from linear probability models that include the same variables as used in the final column of Table 3 . 


\section{Table 5: Union Effects on Employer Offers of Health Insurance, RWJF Establishment Data}

\begin{tabular}{|c|c|c|c|c|}
\hline \multirow[b]{4}{*}{ All Establishments } & \multicolumn{2}{|c|}{$\begin{array}{c}\text { Health Insurance } \\
\text { Offer Rates }\end{array}$} & \multicolumn{2}{|c|}{$\begin{array}{c}\text { Difference } \\
\text { (union - non-union) }\end{array}$} \\
\hline & (1) & (2) & (3) & (4) \\
\hline & Union & Non-union & Unadjusted & Adjusted \\
\hline & .989 & .836 & $\begin{array}{c}.153 \\
(.006)\end{array}$ & $\begin{array}{l}.029 \\
(.005)\end{array}$ \\
\hline \multicolumn{5}{|l|}{ By Establishment Size } \\
\hline$<10$ employees & .875 & .524 & $\begin{array}{l}.351 \\
(.030)\end{array}$ & $\begin{array}{l}.272 \\
(.029)\end{array}$ \\
\hline 10 to 24 employees & .945 & .746 & $\begin{array}{l}.199 \\
(.025)\end{array}$ & $\begin{array}{l}.147 \\
(.024)\end{array}$ \\
\hline 25 to 49 employees & .985 & .859 & $\begin{array}{l}.126 \\
(.022)\end{array}$ & $\begin{array}{l}.080 \\
(.022)\end{array}$ \\
\hline 50 to 99 employees & .968 & .922 & $\begin{array}{l}.046 \\
(.017)\end{array}$ & $\begin{array}{l}-.004 \\
(.017)\end{array}$ \\
\hline 100 to 249 employees & .990 & .957 & $\begin{array}{l}.033 \\
(.012)\end{array}$ & $\begin{array}{l}.017 \\
(.013)\end{array}$ \\
\hline $250+$ employees & .999 & .997 & $\begin{array}{l}.002 \\
(.003)\end{array}$ & $\begin{array}{l}.004 \\
(.004)\end{array}$ \\
\hline
\end{tabular}

Note: All figures are employee-weighted. Standard errors are in parentheses. Sample sizes are reported in Table 2. Adjusted differences are based on linear probability model regressions. The regression specification includes indicator variables for establishment size (full sample only; 6 categories), industry (10 categories), state, the number of years the firm has been operating, and whether or not the firm has another location. The model also includes controls for the percentage of workers in four demographic categories (males under age 25, females under age 25, females 25 to 54, males 55 and older, females 55 and older). 
Table 6: Union Effects on the Employer's Share of Premium Payments, RWJF Establishment Data

(1) (2)

(3)

(4)

(5)

\begin{tabular}{|c|c|c|c|c|c|}
\hline \multirow{2}{*}{$\begin{array}{l}\text { Employer's Percentage } \\
\text { Share of: }\end{array}$} & \multirow[t]{2}{*}{$\begin{array}{c}\text { Union, } \\
\text { Unadjusted }\end{array}$} & \multirow[t]{2}{*}{$\begin{array}{l}\text { Non-union, } \\
\text { Unadjusted }\end{array}$} & \multirow[t]{2}{*}{$\begin{array}{c}\text { Non-union, } \\
\text { Adjusted }\end{array}$} & \multicolumn{2}{|c|}{$\begin{array}{c}\text { Difference } \\
\text { (union - non-union) }\end{array}$} \\
\hline & & & & Unadjusted & Adjusted \\
\hline \multicolumn{6}{|l|}{ Single Coverage Premium } \\
\hline Mean Percentage & 88.3 & 81.8 & 79.2 & 6.5 & 9.1 \\
\hline Median Percentage & 98 & 89 & 85 & 9 & 13 \\
\hline$\%$ of Employers Paying Full & $49.4 \%$ & $37.9 \%$ & $29.9 \%$ & $11.5 \%$ & $19.5 \%$ \\
\hline number of observations & 2,635 & 16,815 & 16,815 & -- & -- \\
\hline \multicolumn{6}{|l|}{ Family Coverage Premium } \\
\hline Mean Percentage & 76.3 & 64.9 & 66.2 & 11.4 & 10.1 \\
\hline Median Percentage & 81 & 70 & 75 & 11 & 6 \\
\hline$\%$ of Employers Paying Full & $27.6 \%$ & $15.9 \%$ & $12.6 \%$ & $11.7 \%$ & $15.0 \%$ \\
\hline number of observations & 2,615 & 16,487 & 16,487 & -- & -- \\
\hline
\end{tabular}

Notes: The employer's share of premiums is expressed in percentage terms. All statistics are weighted by plan enrollment. Adjusted non-union figures also are weighted by conditioning weights that account for union - non-union differences in the distribution of establishment characteristics, as described in the text. The list of establishment characteristics is the same as in Table 5. 
Table 7: Union Effects on Retiree Health Benefits, 1988 and 1993 CPS

(1) (2) (3) (4)

Panel A: 1988 Retiree Health Insurance Supplement (N=1098)

\begin{tabular}{lccccc} 
& & \multicolumn{3}{c}{ Difference (union - non-union) } \\
\cline { 3 - 5 } Retiree & Union & Non-union & Unadjusted & Adjusted & Adjusted (size) \\
Coverage & .740 & .639 & .101 & .045 & N/A \\
& & & $(.031)$ & $(.034)$ &
\end{tabular}

Panel B: 1993 Benefits Supplement (N=1806)

\begin{tabular}{lccccc} 
& & \multicolumn{3}{c}{ Difference (union - non-union) } \\
\cline { 3 - 5 } Retiree & Union & Non-union & Unadjusted & Adjusted & Adjusted (size) \\
Coverage & .766 & .598 & .167 & .146 & .128 \\
& & & $(.027)$ & $(.029)$ & $(.028)$ \\
Employer Pays & .253 & .127 & .126 & .099 & .099 \\
Full Cost & & & $(.026)$ & $(.029)$ & $(.029)$ \\
\hline \hline
\end{tabular}

Note: All estimates were obtained using the survey supplement weights. Standard errors are in parentheses. The adjusted union effects in columns (4) and (5) are the union coefficients from linear probability models that include the same variables as listed at the bottom of Table 3 . Each sample is restricted to private sector employees aged 46-64 who at the time of the survey were receiving employer-provided health insurance in their name. The 1993 employer cost-share regression is restricted to the 979 individuals whose employers provide retiree coverage and for whom the cost-share information is not missing.

$\mathrm{N} / \mathrm{A}=$ not available 


\section{Table 8: Union Effects on Retiree Health Benefits, RWJF Data, by Establishment Size}

\begin{tabular}{|c|c|c|c|c|c|}
\hline & \multirow{3}{*}{$\begin{array}{l}(1) \\
\text { Sample } \\
\text { Size }\end{array}$} & \multicolumn{2}{|c|}{$\begin{array}{c}\text { Retiree } \\
\text { Health Insurance } \\
\text { Offer Rates }\end{array}$} & \multicolumn{2}{|c|}{$\begin{array}{c}\text { Difference } \\
\text { (union - non-union) }\end{array}$} \\
\hline & & (2) & (3) & (4) & $(5)$ \\
\hline & & Union & Non-union & Unadjusted & Adjusted \\
\hline All Establishments & 14,739 & .559 & .308 & $\begin{array}{l}.251 \\
(.009)\end{array}$ & $\begin{array}{l}.079 \\
(.009)\end{array}$ \\
\hline \multicolumn{6}{|l|}{ By Establishment Size } \\
\hline$<10$ employees & 5,182 & .313 & .152 & $\begin{array}{l}.161 \\
(.025)\end{array}$ & $\begin{array}{l}.118 \\
(.025)\end{array}$ \\
\hline 10 to 24 employees & 4,164 & .267 & .162 & $\begin{array}{l}.104 \\
(.023)\end{array}$ & $\begin{array}{l}.060 \\
(.023)\end{array}$ \\
\hline 25 to 49 employees & 2,029 & .283 & .179 & $\begin{array}{l}.104 \\
(.027)\end{array}$ & $\begin{array}{l}.101 \\
(.027)\end{array}$ \\
\hline 50 to 99 employees & 1,385 & .413 & .185 & $\begin{array}{l}.228 \\
(.028)\end{array}$ & $\begin{array}{l}.167 \\
(.029)\end{array}$ \\
\hline 100 to 249 employees & 1,211 & .438 & .242 & $\begin{array}{l}.196 \\
(.030)\end{array}$ & $\begin{array}{l}.164 \\
(.032)\end{array}$ \\
\hline $250+$ employees & 777 & .668 & .581 & $\begin{array}{l}.087 \\
(.036)\end{array}$ & $\begin{array}{l}.044 \\
(.035)\end{array}$ \\
\hline
\end{tabular}

Note: All figures are employee-weighted. The sample is restricted to establishments offering health insurance to active employees. Standard errors are in parentheses. Adjusted differences are based on linear probability model regressions that control for the same establishment characteristics as listed at the bottom of Table 5. 